\title{
10 \\ When is Emotional Distress Harm?
}

\author{
GREGORY C KEATING*
}

$\mathrm{T}$

1HE ARC OF American negligence law's treatment of emotional distress over the course of the past century may be the most striking trajectory in the modern history of torts. For almost 70 years, liability for the infliction of emotional distress expanded inexorably but incrementally. In 1968, however, this incremental advance was summarised into a sweeping general principle. The California Supreme Court-the most important and influential common law court in the country-declared triumphantly that only the acknowledgement of a bold general principle could justify the liability that had been slowly building and that, henceforth, liability for the accidental infliction of emotional distress would be governed by the same principle of reasonable foreseeability that governed liability for the unreasonable infliction of physical harm. ${ }^{1}$ In retrospect, the court's triumphant tone was deeply ironic. The opinion in Dillon $v$ Legg heralds the coming of age of liability for the negligent infliction of emotional distress, but turns out to mark the high water mark of such liability and to initiate its retreat. Two decades later, the California Supreme Court would beat a sharp retreat from both Dillon's commitments and the century-long expansion of liability for emotional injury.

Indeed, Dillon marked the end of an age of American tort law-the age when reasonable foreseeability of harm rose to pre-eminence as the fundamental principle of the law of negligence, and transformed not only the law of torts, but the landscape of private law. Privity of contract as a precondition of product liability and the status categories of landowner liability were both casualties of the rise of reasonable foreseeability. Product and premises liability were its progeny. The transformed landscape left by the triumph of reasonable foreseeability within the law of negligence, and by

\footnotetext{
* I am grateful to the participants at the Obligations VI Conference, especially Ben Zipursky and John Goldberg for perceptive comments and criticism. I am indebted to Nicole Creamer for research and editorial assistance.

1 Dillon v Legg 441 P 2d 912, 68 Cal 2d 728 (1968) [Dillon].
} 


\section{Gregory C Keating}

the triumph of tort over contract and property, is the landscape of private law in our time.

Reasonable foreseeability began its rise as the first principle of negligence law in 1916, when MacPherson v Buick Motor Co declared reasonable foreseeability of physical harm to be the master principle of duty in the law of negligence. ${ }^{2}$ When 'danger is to be foreseen', MacPherson declared, 'there is a duty to avoid the injury' - a duty which arises 'irrespective of contract'. ${ }^{3}$ Tort therefore trumped contract in the domain of product liability. The principle of reasonable foreseeability continued its ascendance in Palsgraf $v$ Long Island Railroad, when Cardozo J's majority opinion declared reasonable foreseeability to be the master test for the scope of liability (proximate cause) as well as the master test for the existence of obligation (duty). ${ }^{4}$ The scope of liability must track the grounds of duty, Palsgraf insisted: '[ $t$ ]he risk reasonably to be perceived defines the duty to be obeyed'. ${ }^{5}$

The rise of reasonable foreseeability reached its zenith in 1968. Rowland $v$ Christian held that, henceforth, tort principles-not the status categories of property law (trespasser, licensee, invitee)—should govern the obligations owed to entrants on real property. ${ }^{6}$ Just as tort triumphed over contract in MacPherson, so too tort triumphed over property in Rowland. Dillon, for its part, declared liability for the negligent infliction of emotional distress (NIED) would no longer be governed by special and arbitrarily restrictive rules. The general principle of reasonable foreseeability would rule here as well. The scope of liability for emotional distress actually inflicted would be determined by the scope of foreseeable emotional distress unreasonably risked. ${ }^{7}$

A scant 20 years later, however, the very same court concluded that reasonable foreseeability

'proves too much.... Although it may set tolerable limits for most types of physical harm, it provides virtually no limit for nonphysical harm'... It is apparent that reliance on foreseeability of injury alone in finding duty and thus a right to recover, is not adequate when damages sought are for an intangible injury. ${ }^{8}$

The age of reasonable foreseeability had come to a close. Cabining liability for NIED through the use of arbitrary rules returned to vogue. The Reporter's Memorandum to Tentative Draft No 5 of the Restatement

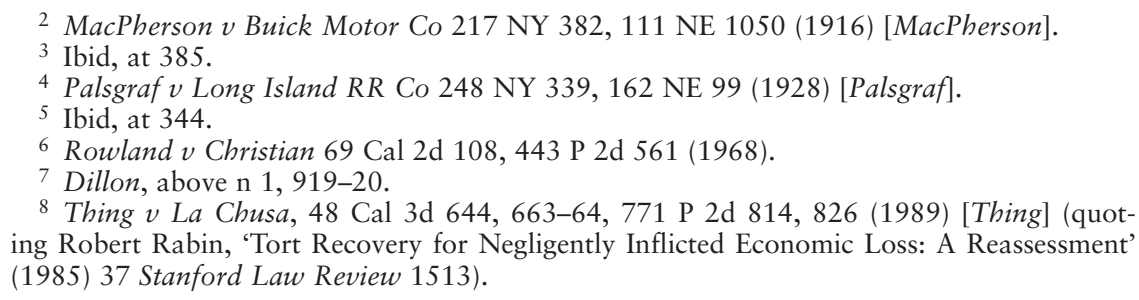


(Third) of Torts testifies to this transformation; it declares openly that the boundaries of liability for NIED must be drawn arbitrarily. ${ }^{9}$ American negligence law is now plagued by an inability to fix the boundaries of liability for emotional distress in a way which reflects a principle more discriminating than the principle that liability must have some limit. Formally, American courts and commentators have done well. De facto, they have configured NIED liability as a matter of proximate cause, not duty. This is a sound place to slot a domain of liability whose principal problem is its tendency towards excessive expansion. Determining the limits of liability is, after all, the distinctive role of proximate cause doctrine. Substantively, American courts and commentators have struggled. Their repudiation of the principle of reasonable foreseeability as the cornerstone of liability for NIED has left them unable to circumscribe liability in a coherent and defensible way.

Courts and commentators are at sea because emotional distress stands in an elusive and ambiguous relation to harm. The law of torts is, for the most part, a law of liability for harm wrongly inflicted. Reasonable foreseeability of harm triggers the imposition of a duty of care. Harm is not injury, cost or loss-a lesson driven home by the pure emotional injury and pure economic loss rules. Some emotional distress is rightly regarded as harm but other emotional distress is better regarded as loss or injury. Some emotional distress belongs within the scope of liability for harm wrongly done. Other emotional distress does not. In order to circumscribe NIED liability in a principled way we must discriminate between those instances of emotional distress which constitute, or mark, the suffering of harm and those which do not. Or so I shall argue.

\section{HARM, LOSS AND EMOTIONAL DISTRESS IN TORT}

\section{A. Harm and Loss in the Law of Torts}

Harm is an indispensable element of most torts. '[N]egligence', the Restatement (Second) of Torts reports, 'is conduct which falls below the standard established by law for the protection of others against unreasonable risk of harm'. ${ }^{10}$ With rare exceptions, ${ }^{11}$ intentional torts and claims

${ }^{9}$ Restatement (Third) of Torts: Liability for Physical \& Emotional Harm (Tentative Draft No 5) (2007) xxi [Tentative Draft No 5].

10 Restatement (Second) of Torts (1965) $\$ 282$.

11 The exceptions involve torts like trespass, conversion, and battery in some of its incarnations. These torts protect zones of discretionary choice (over one's physical person, against unauthorised invasion) and can be committed without harming their victims and, indeed, while benefitting their victims. These torts may be linked to harm-based ones by the fact that, in both cases, the agency of the victim is thwarted. Harms leave their victims in conditions 
for accidental injury predicated on strict liability also require the infliction of harm. For the most part, tort law has taken harm to mean physical harm, and harm itself has been understood as impairment. In 1934, the Restatement (First) of Torts defined bodily harm as 'any impairment of the physical condition of another's body or physical pain or illness'. ${ }^{12}$ The Restatement (Third) now defines 'physical harm' as 'the physical impairment of the human body ("bodily harm") or of real property or tangible personal property... [such impairment] includes physical injury, illness, disease, impairment of bodily function, and death'.13

Harm is also a subject of special moral concern ${ }^{14}$ because harm is presumptively bad to suffer and presumptively wrong to inflict. In tort law, moreover, harm is distinguished from mere loss in that suffering physical harm is usually a prerequisite for liability. Suffering 'pure economic loss' or 'pure emotional distress', by contrast, generally will not trigger duty in tort. ${ }^{15}$ There is deep and sound reason in this distinction: harms leave their victims in conditions where their agency is disabled whereas losses-even crushing ones-usually do not. Athletes who come up a few inches short in Olympic competition are surely profoundly disappointed and distressed by their losses, but they are not usually left disabled, disfigured or physically impaired. The distinction between harm and loss is thus both morally significant and fundamental to the law of torts.

Yet even though the distinction between harm and loss is fundamental it is also elusive. Harm is not a sharply defined concept. '[T]he word', as Judith Thomson says, 'slithers'. ${ }^{16}$ The boundary between harm and loss is often unclear. Intuitively, moreover, some losses seem manifestly worse than other harms. An Olympic athlete would surely prefer suffering a minor sprain to losing a medal by inches, even though the sprain is a harm and the defeat a mere loss. In part, no doubt, because harm is a slippery concept the 'pure economic loss' and 'pure emotional injury' rules are plagued by exceptions. ${ }^{17}$ Were the law of torts a person, it might be taken to be beset by doubt as to whether and when it should insist on the significance of the distinction between harm and loss.

where their agency is impaired. Wrongs which violate rights of control over zones of discretionary choice having to do with one's person and property also damage the agency of their victims in a fundamental way. For a more complete analysis of this see G Keating, 'Priority of Respect Over Repair' (2012) 18 Legal Theory 293, 315-16.

12 Restatement (First) of Torts (1934) \$ 15.

13 Restatement (Third) of Torts: Liability For Physical \& Emotional Harm (2010) $\mathbb{\$} 4$.

14 Seana Shiffrin develops this point forcefully in 'Harm and its Moral Significance' (2012) 18 Legal Theory 357.

15 This is particularly evident in the case of general negligence liability.

16 J Thomson, The Realm of Rights (Cambridge, Mass, Harvard University Press, 1990) 260.

17 Judge (now Justice) Stephen Breyer plausibly counts nine exceptions to the pure economic loss rule in his opinion in Barber Lines v Donau Maru 764 F 2d 50, 56 (1st Cir 1985). 
The general difficulty of distinguishing harm and loss is especially acute in the case of emotional distress. Few problems have troubled the law of torts as much or as long. Recovery for emotional distress began to emerge around the turn of the twentieth century, percolated slowly for the first half of the century, and then blossomed rapidly but only to wither significantly toward the end of the century. ${ }^{18}$ Over the course of this history courts wrestled with whether and when emotional distress constitutes harm. ${ }^{19}$ Even today, as the law of recovery for NIED stabilises, courts and commentators have great difficulty fashioning satisfactory justifications of the law that courts have, in fact, constructed.

The Reporter's Memorandum to Tentative Draft No 5 testifies to American tort law's present predicament when it concedes:

There is a recurring (and new) theme in these materials: the use of arbitrary lines to limit recovery for emotional disturbance ... In many instances, one could persuasively argue that such restrictions are no more appropriate or rational than an alternative limitation and so, in that sense, are arbitrary. We agree with that

18 GE White, Tort Law in America: An Intellectual History, rev'd edn (New York, Oxford University Press, 1985) 102-4, is a good brief discussion of the emergence of recovery for emotional distress in the first third of the 20th century. The recognition of the right to recover for pure emotional distress began with the recognition of physical harm inflicted by emotional mechanisms (eg, by shock and fright). Francis Bohlen, the Reporter for the Restatement (First) of Torts, made the case for such recovery in 1902. F Bohlen, 'Right to Recovery for Injury Resulting from Negligence Without Impact’ (1902) 50 American Law Register 141. Early cases were powerfully gendered. A classic fact pattern involved a pregnant woman suffering fright and miscarrying. See, eg, Hill $v$ Kimball 76 Tex 210, 13 SW 59 (1890) [ Hill]. The classic study of the gendered aspect of the history of recovery for emotional distress is M Chamallas and L Kerber, 'Women, Mothers and the Law of Fright: A History' (1990) 88 Michigan Law Review 814. The next phase in the evolution of recovery for emotional distress involved the recognition of a freestanding tort for intentional infliction of emotional distress. Several academic articles nursed the birth of this tort. See especially C Magruder, 'Mental and Emotional Disturbance in the Law of Torts' (1936) 49 Harvard Law Review 1033; WL Prosser, 'Intentional Infliction of Mental Suffering: A New Tort' (1939) 37 Michigan Law Review 874. The expansion of negligence liability for emotional distress is identified with Dillon, above $\mathrm{n} 1$, and the subsequent contraction with Thing, above n 8. Dillon is the decisive case for our time. The rules governing negligence liability for pure emotional distress adopted in $\mathbb{S} 46$ and 47 of the pending Restatement (Third) tweak the regime of Dillon and its aftermath. Indeed $\mathbb{} 47$ 'reflects the rule first adopted by the California Supreme Court in Dillon v Legg': Tentative Draft No 5, above n 9, at $\mathbb{S} 47$ (cmt A).

19 Clark v Associated Retail Credit Men of Washington DC 105 F 2d 62, 64 (DC Cir 1939) [Clark] commented on the perceived erosion of the hard and fast line between physical harm and mental suffering: '[L]awyers have begun to learn from doctors and physiologists that "We fear not in our hearts alone, not in our brains alone, not in our viscera alone-fear influences every organ and tissue." "And what is true of fear is true in kind, though not in degree, of the lesser emotions such as worry and anxiety." The tendency of the law to ignore "mental" harm diminishes.' There is a brief review of relevant history in Comment b. Bodily Harm Distinguished to $\mathbb{4} 45$ of the Tentative Draft No 5, above $\mathrm{n} 9$. This history is hardly over. Recent advances in neuroimaging may instil increased confidence in our capacity to verify the presence of emotional harm. 
assessment-while cautioning that, given the ubiquity of emotional disturbances, lines must be drawn. ${ }^{20}$

The inability to fix the boundaries of liability for emotional distress in a way which reflects a principle more discriminating than the principle that liability must have some limit is only one of two difficulties which continue to plague the law of NIED. The other enduring difficulty is taxonomical: What kind of doctrine is NIED? Is it a doctrine of 'duty'? Is it a doctrine about proximate cause or scope of liability? Or is it something else entirely?

The prevailing wisdom is that the obligation not to inflict serious emotional distress negligently is a freestanding obligation or duty, and a deeply problematic one. ${ }^{21}$ This chapter will challenge this orthodoxy by arguing that American NIED law has largely solved the problem of 'duty'. ${ }^{22}$ To grasp that solution we must first summarise the architecture of liability for NIED. The cornerstone of that architecture is the division of NIED liability into two branches: (1) a bystander branch, and (2) a pre-existingrelationship branch.

The bystander branch (covered by $\mathbb{S} 47$ of the Restatement (Third) and by $\mathbb{S} 46(\mathrm{a})$ as well) addresses the circumstance where the victim of severe emotional distress is a bystander to the imposition of a risk of physical harm. That risk either does not materialise at all, or materialises to another person. The complaining plaintiff has suffered only serious emotional distress; physical harm was negligently risked, but fortuitously avoided. In these cases the relevant duty is the general negligence duty not to risk physical harm unreasonably. In the second kind of case (covered by $\mathbb{S} 46(\mathrm{~b})$ ), emotional distress occurs in the context of a pre-existing relationship (eg, physician-patient) whose existence is taken to impose an independent, preexisting duty of care.

The critical point is this: neither branch of NIED law itself imposes the pertinent duty of care. Both branches extend liability for breach of an independently recognised duty of care to cover some emotional distress. Because

20 Tentative Draft No 5, ibid, at xxi.

21 John Goldberg and Ben Zipursky took this view of the matter in their plenary address at the Obligations VI Conference: 'Negligent Infliction of Emotional Distress and Tort Orthodoxy' (London, ON, July 2012). Dillon, the most influential and important of modern American NIED cases, has managed to both foster and undermine this view. The case itself contains one of the greatest denunciations ever penned of 'duty' as an element of negligence law. The Dillon court's assault on 'duty' limitations, however, bred a backlash against the broad liability implied by the opinion's expansive rhetoric. This post-Dillon retrenchment has often been seen as the resuscitation of duty limits, or as proof that NIED liability is plagued by duty problems.

22 The solution fashioned by courts will not satisfy Professors Goldberg and Zipursky because they object to the dominant conception of duty in American tort law. My point is that contemporary American courts have achieved two objectives. First, they have placed manageable limits on NIED liability and constructed a coherent body of doctrine. Second, their solution is coherent with the dominant way of conceiving of duty in modern American negligence law. That conception takes duty to be about the existence of obligation. 
modern American courts finesse duty determinations in this way, 'there is no general duty not to negligently inflict emotional distress' in American law. ${ }^{23}$ Liability for NIED is a matter of the scope (or extent) of a defendant's responsibility for breach of an independent duty of care-that is, a duty which is not predicated primarily on the prospect that serious emotional distress will ensue if reasonable care is not exercised. Taxonomically speaking, this makes NIED liability a matter of 'proximate cause' or scope of liability, not duty.

To be sure, NIED liability presents an atypical type of proximate cause question. The issue presented is whether liability extends to this kind of harm - to the emotional distress before the court. Proximate cause cases addressing 'type of harm' are hardly unknown-pure economic loss cases address the same general question-but they appear to be both less common and more difficult than cases where, say, remoteness of loss is the issue. Courts and commentators wrestling with the scope of liability for NIED have despaired of doing better than drawing avowedly arbitrary lines limiting recovery on the ground that liability must come to an end somewhere. They have not been able to say with any confidence that some emotional distress is harm whereas other emotional distress is not. The principal task of this chapter is to examine whether courts might do better in this regard.

\section{B. Liability for Negligent Infliction of Emotional Distress}

Dillon, the most important of modern NIED cases, powerfully frames the issues at stake in NIED liability. Legg's negligent driving killed a young child, Erin Lee Dillon, whose mother and sister were nearby. Each witnessed the collision, neither suffered physical harm, but each allegedly suffered 'great emotional disturbance and shock' and 'injury to her nervous system'. Lower courts allowed the sister's claim to stand, but dismissed the mother's claim, on the ground that the sister had been-whereas the mother had not been-close enough to the accident to have feared for her own safety. ${ }^{24}$ The California Supreme Court responded to this distinction by overruling the 'zone of danger rule' ${ }^{25}$

[W]e have before us a case that dramatically illustrates the difference in result flowing from the alleged requirement that a plaintiff cannot recover for emotional

23 Boyles $v$ Kerr 855 SW 2d 593, 597 (1992). Boyles is speaking of Texas law but the point holds more generally.

24 Dillon, above $\mathrm{n} 1$, at 915.

25 The 'zone of danger' rule permits a plaintiff whose physical safety was endangered by a negligent actor to recover for her emotional distress, even if she is not physically harmed by that negligence. It denies recovery to a bystander who witnesses the very same horrific accident and experiences identical emotional trauma, but who is not physically endangered by the negligent conduct in question. ibid, at 915-16. 
trauma in witnessing the death of a child or sister unless she also feared for her own safety because she was actually within the zone of physical impact.

... The case ... illustrates the fallacy of the rule that would deny recovery in the one situation and grant it in the other. In the first place, we can hardly justify relief to the sister for trauma which she suffered upon apprehension of the child's death and yet deny it to the mother merely because of a happenstance that the sister was some few yards closer to the accident. The instant case exposes the hopeless artificiality of the zone-of-danger rule. In the second place, to rest upon the zone-of-danger rule when we have rejected the impact rule becomes even less defensible. We have, indeed, held that impact is not necessary for recovery. The zone-of-danger concept must, then, inevitably collapse because the only reason for the requirement of presence in that zone lies in the fact that one within it will fear the danger of impact. ${ }^{26}$

The court went on to hold that liability for NIED in California would henceforth be governed by general negligence principles, with reasonable foreseeability of harm being the touchstone of responsibility. ${ }^{27}$ Liability for emotional anguish ought to be treated on a par with physical harm; the scope of anguish unreasonably risked ought to determine the extent of liability for distress suffered.

Dillon presents itself as the triumphant culmination of decades of common law development. The seed from which it sprang was planted when courts repudiated the physical impact rule by recognising liability for the infliction of physical harm through visceral emotional mechanisms. Cases where shock causes miscarriage were the canonical instances of this first step in the demise of the physical impact rule. ${ }^{28}$ The requirement that emotional distress cause physical harm was in turn abandoned when two developments took place. First, the deliberate infliction of severe emotional distress was recognised as a freestanding tort. Second, negligence law-echoing the tort of assault-recognised liability for emotional harm suffered because

26 Ibid, at 915.

27 See above $\mathrm{n} 7$ and accompanying text.

28 The physical impact rule itself is stated clearly in Spade $v$ Lynn \& Boston RR Co 168 Mass 285, 47 NE 88, 89 (1897): 'There can be no recovery for fright, terror, alarm, anxiety, or distress of mind, if these are unaccompanied by some physical injury; and, if this rule is to stand we think it should also be held that there can be no recovery for such physical injuries as may be caused solely by such mental disturbance; where there is no injury to the person from without'. Examples of recovery for physical harm caused by visceral emotional distress include Hill, above $\mathrm{n} 18$ (miscarriage caused by the shock of witnessing defendant beating two men in her yard); and Price v Yellow Pine Paper Mill Co 240 SW 588, 594 (Tex Civ App 1922) (physical and emotional damages sustained as a result of fright experienced when her husband was brought home bloody and unconscious after an on-the-job accident). The common law history was traced by Calabresi J in Nelson v Metro-North Commuter Railroad 235 F 3d 101, 105-6 (2d Cir 2000). The fright cases which overthrow the impact rule are deeply entangled with gender, as is Dillon itself. See Chamallas and Kerber, above n 18. 
the victim feared imminent physical harm. ${ }^{29}$ Dillon presents its ruling as the law finally working itself pure: liability for emotional distress must be unfettered from liability for physical harm. Emotional tranquility must be recognised as an interest worthy of protection in its own right.

The court's reasoning was simple, if sweeping. First, Dillon asserted that reasonable foreseeability of harm was the master principle of duty in negligence law:

The obligation turns on whether 'the offending conduct foreseeably involved unreasonably great risk of harm to the interests of someone other than the actor ... [T] he obligation to refrain from ... particular conduct is owed only to those who are foreseeably endangered by the conduct and only with respect to those risks or hazards whose likelihood made the conduct unreasonably dangerous. Duty, in other words, is measured by the scope of the risk which negligent conduct foreseeably entails. ${ }^{30}$

Second, the court asserted that emotional harm should be governed by the same principle of foreseeability as physical harm:

[F]oreseeable risk may be of two types. The first class involves actual physical impact. A second type of risk applies to the instant situation. '.. plaintiff is outside the zone of physical risk (or there is no risk of physical impact at all), but bodily injury or sickness is brought on by emotional disturbance which in turn is caused by defendant's conduct. Under general principles recovery should be had in such a case if defendant should foresee fright or shock severe enough to cause substantial injury in a person normally constituted. Plaintiff would then be within the zone of risk in very much the same way as are plaintiffs to whom danger is extended by acts of third persons, or forces of nature, or their own responses (where these things are foreseeable). 31

The 'zone of danger' rule must fall just as the 'physical impact' and 'physical harm' rules did because it, too, is an arbitrary limit on the master principle of duty in negligence law: 'The risk reasonably to be perceived defines the duty to be obeyed'. ${ }^{32}$ Margery Dillon should (and does) recover not because she was at foreseeable risk of physical harm, but because she was at foreseeable risk of emotional harm.

29 The tort of IIED was recognised for the first time by State Rubbish Collectors Ass' $n v$ Siliznoff 240 P 2d 282 (Cal 1952) (Traynor J). See also Magruder, above n 18. The logic of abandoning the physical harm rule by allowing recovery for fear of physical harm was pithily summarised by Consolidated Rail Corp v Gottshall 512 US 532, 556, 114 S Ct 2396, 2411 (1991): 'We see no reason ... to allow an employer to escape liability for emotional injury caused by the apprehension of physical impact simply because of the fortuity that the impact did not occur'.

30 Dillon, above n 1, at 920 (quoting FV Harper and F James, The Law of Torts (Boston, Little, Brown, 1956) 1018).

31 Dillon, above n 1, at 920 (quoting Harper and James, above n 30, at 1035-36). The 'zone-of-danger' rule itself already repudiates the physical injury requirement that Harper and James mention.

32 Dillon, above n 1, at 919 (citing Palsgraf, above n 4, at 344). 
The Dillon opinion also bears witness to immensely powerful intuitions triggered by its facts. The death of a child-witnessed or not-may be the event that every parent fears the most, far more than their own deaths. Parents generally expect and hope to die before their children. They count themselves unlucky when they do not. 'It is horrible to see oneself die without children. Napoleon Bonaparte said that. What greater grief can there be for mortals than to see their children dead. Euripedes said that'. ${ }^{33}$ Erin Lee Dillon's death devastated her mother's life as much as any physical harm might have. That grim fact powerfully supports the Dillon court's conclusion that the law of torts should treat emotional and physical harm equally.

Yet for all the power of its facts and the force of its reasoning, the most evident effect of Dillon was to cause the very same court to repudiate reasonable foreseeability as the measure of responsibility for pure emotional harm and to construct another-apparently equally arbitrary-rule to govern the scope of such liability. As indicated, a mere 20 years later the California Supreme Court wrote in Thing $v$ La Chusa:

The Dillon experience confirms, as one commentator observed, that '[f]oreseeability proves too much .... Although it may set tolerable limits for most types of physical harm, it provides virtually no limit on liability for nonphysical harm.' It is apparent that reliance on foreseeability of injury alone ... is not adequate when the damages sought are for an intangible injury. In order to avoid limitless liability out of all proportion to the degree of a defendant's negligence, and against which it is impossible to insure without imposing unacceptable costs on those among whom the risk is spread, the right to recover for negligently caused emotional distress must be limited. ${ }^{34}$

Making reasonable foreseeability of pure emotional harm the test of duty turned out to be self-defeating. Instead of giving liability for emotional harm a secure place in the law of negligence, it set courts searching for ways to curtail such liability.

Thing therefore domesticated Dillon's principle that the risk reasonably to be perceived determines the scope of responsibility for harm done by converting its general 'guidelines' into a hard and fast rule:

[A] plaintiff may recover damages for emotional distress caused by observing the negligently inflicted injury of a third person if, but only if, said plaintiff: (1) is closely related to the injury victim; (2) is present at the scene of the injuryproducing event at the time it occurs and is then aware that it is causing injury to the victim; and (3) as a result suffers serious emotional distress-a reaction

33 J Didion, Blue Nights (New York, Alfred A Knopf, 2011) 13 continues: 'When we talk about mortality we are talking about our children. I said that'.

34 Thing, above n 8, at 826-27, citing Rabin, above n 8, at 1526 . This passage is also quoted in Tentative Draft No 5, above $\mathrm{n} 9$, at $\mathbb{\$} 46$ (reporters' note $(\mathrm{cmt} \mathrm{f})$ ). 
beyond that which would be anticipated in a disinterested witness and which is not an abnormal response to the circumstances. ${ }^{35}$

Parents who witness the deaths of their children may recover for their own trauma, but parents who learn secondhand that their children have suffered such fates may not. One may reasonably doubt that the latter parent is much less distressed.

By limiting Dillon in this way, Thing reversed the course of nearly a century of common law development. Dillon thus struck down as 'artificial' the 'zone of danger' limitation on recovery for emotional distress only to be itself cabined, two decades later, by a comparably artificial distinction between witnessing firsthand and learning secondhand of the death of one's child. Neither categorical distinction tracks at all precisely either the severity or the reasonableness of emotional distress. Witnessing the death of one's child may well be worse than merely hearing about it secondhand, but both are devastating emotional blows. Any gap in severity between them surely does not correspond to the difference between emotional distress that reasonable people should steel themselves against and emotional distress that reasonable people should experience as utterly devastating.

\section{Previewing the Argument}

The remainder of this chapter will proceed as follows. Part II explains how NIED liability manifests itself as one of modern tort law's pre-eminent taxonomical problems, inviting classification as either duty or proximate cause, or as some mix of the two. Duty has to do with the existence of obligation in tort-with whether an interest gives rise to a claim that others conduct themselves carefully to avoid jeopardising that interest-whereas proximate cause has to do with the scope of liability for breach of a recognised obligation. Duty determines standards of conduct; proximate cause determines extent of responsibility. Part III argues that-contrary to conventional wisdom-American tort law not only declines to impose a general duty of care to avoid inflicting emotional anguish, but does not treat NIED liability as a matter of duty. Part IV argues that American tort law's construction of NIED as an extent of responsibility leaves the law lacking an account of harm which would enable courts to distinguish among instances of emotional anguish in a principled way.

Part IV returns to the idea that harms are impairments. To be harmed is to be put in a condition where one's agency is compromised. Physical

35 Thing, above $\mathrm{n} 8$, at 841 . The Dillon court proposed these three criteria as 'factors' whose presence or absence will 'indicate the degree of the defendant's foreseeability': above n 1, at 920-21. Thing thus contracted the scope of NIED liability by converting Dillon's openended standard into a rigid rule. 
harms-broken limbs, illnesses, disabilities, disfigurement-thwart the normal use of one's body. Because our bodies both play a central role in our lives and activities and are vulnerable to all sorts of ailments and injuries, physical impairments are an enduring and fundamental threat to our agency. Psychological integrity plays a similar role in our lives and psychological impairments are similarly capable of doing lasting damage to agency. The law of NIED should take its cue from the idea of harm as impairment, and extend liability to those instances of emotional distress which shatter the lives of those they afflict.

\section{NIED AS A TAXONOMICAL PROBLEM}

Liability for NIED is one of the pre-eminent taxonomical puzzles in present-day tort law. Courts and commentators are divided over whether NIED law imposes a freestanding obligation, or merely delineates the extent of a defendant's responsibility for breaching a pre-existing duty of due care-a duty grounded primarily in considerations other than the prospect of emotional harm. ${ }^{36}$ In the duty model, NIED is a freestanding tort, and the structure of tort liability for emotional distress roughly parallels the structure of tort liability for misrepresentation. Both torts protect important interests: one guards our interest in emotional tranquility while the other guards our interest in not being deceived when we are engaged in commercial transactions.

Both torts provide protections against different modes of interference with the interests that they protect. Misrepresentation is a distinct wrong which can be committed deliberately, carelessly or innocently. Some liability for misrepresentation is liability for fraud-for deliberate, wilful, harmful deception. Other liability for misrepresentation is a species of liability for negligence-for misleading statements that a defendant would not have made had he or she exercised reasonable care. ${ }^{37}$ Still other misrepresentation liability is a species of strict liability. Here, the deception is at once

\footnotetext{
36 Compare J Goldberg and B Zipursky, 'Shielding Duty: How Attending to Assumption of Risk, Attractive Nuisance, and Other "Quaint” Doctrines Can Improve Decision-making in Negligence Cases' (2006) 79 Southern California Law Review 329, 357, with DA Esper and GC Keating, 'Putting “Duty” in Its Place: A Reply to Professors Goldberg and Zipursky' (2008) 41 Loyola of Los Angeles Law Review 1225, 1264-65, 1292-93. The Restatement (Third) takes the position that some NIED cases are 'proximate cause', whereas others are 'duty'. See Tentative Draft No 5, above n 9, at $\mathbb{\$} \mathbb{4} 46-47$.

37 Negligent misrepresentation imposes liability upon certain classes of persons who, in the course of their occupations, supply information for the guidance of a limited class of other persons for use in their business transactions. Liability extends beyond intentional misrepresentations to misrepresentations made without adequate investigation. See, eg, Greycas, Inc $v$ Proud 826 F 2d 1560, 1566 (7th Cir 1987) (Posner J) [Greycas].
} 
deliberate and morally innocent. ${ }^{38}$ The 'duty' model of NIED holds that interference with the interest in emotional tranquility can likewise be deliberate-as it is under the tort of Intentional Infliction of Emotional Distress ('IIED')—or negligent, as it is in the case of NIED.

In the case of misrepresentation, negligent misrepresentation is grounded on a freestanding duty of care owed: (1) by the occupants of certain social roles; to (2) those who may justifiably rely on the information that occupants of those social roles provide; who (3) are likely to suffer economic loss if those subject to the duty supply inaccurate information. Liability for negligent misrepresentation thus imposes an obligation of conduct on certain kinds of actors: exercise due care when providing 'information for the guidance of others in business transactions'. ${ }^{39}$ The conduct made tortious is distinct both from the deliberate deception that is the hallmark of intentional misrepresentation and from the innocent mistake that characterises misrepresentations subject to strict liability.

Scholars who conceive of NIED as a freestanding tort believe that liability for the infliction of emotional distress has the same basic structure as the misrepresentation torts. ${ }^{40}$ IIED and NIED are freestanding torts bound together by their shared task of protecting people's interest in 'emotional tranquility'. ${ }^{41}$ They differ in the same way that intentional misrepresentation differs from negligent misrepresentation. IIED proscribes conduct which aims at shattering a plaintiff's emotional tranquility (or recklessly

38 The liability imposed on innocent misrepresentations is intimately connected with contract law. Some, but not all of it, is warranty liability. See R Keeton et al, Tort and Accident Law: Cases and Materials, 4th edn (St Paul, Minn, Thomson/West, 2004) 270-76.

39 Penrod $v$ Merrill Lynch, Pierce, Fenner \& Smith, Inc 385 NE 2d 376, 381, 68 Ill App 3d 75, 81 (1979) (quoting Restatement (Second) of Torts (1977) \$552(1)). Lawyers, accountants and land surveyors are among those whose occupational responsibilities sometimes bring them under the jurisdiction of the tort.

40 The Restatement (Third) itself tends to express this view of NIED insofar as the two sections on NIED ( $\mathbb{S} 46$ and 47) follow the one section covering IIED ( $\mathbb{S} 45)$. Tentative Draft No 5 , above $\mathrm{n} 9$, at $\mathbb{S} \mathbb{S 4 5 - 4 7}$. This suggests a single interest protected against different forms of invasion. Section 47, however, lends itself to characterisation as proximate cause because it presents its domain as one where liability for emotional harm is parasitic on liability for physical harm to others. The view of NIED as an independent tort protecting the interest in emotional tranquility against negligent invasion may well be the prevailing view among commentators. Professor John Diamond describes his article as addressing the tort 'for negligently inflicted mental distress'. J Diamond, 'Rethinking Compensation for Mental Distress: A Critique of the Restatement (Third) $\mathbb{S}$ S 45-47' (2008) 16 Virginia Journal of Social Policy and the Law 141, 142. Courts sometimes speak in similar terms and were especially inclined to do so during the 20 years separating Dillon from Thing. See, eg, Paugh v Hanks $451 \mathrm{NE} \mathrm{2d}$ 759, 767, 6 Ohio St 3d 72, 80 (1983): '[W]e hold that freedom from the negligent infliction of serious emotional distress is entitled to independent legal protection'.

41 This description of the interest protected by NIED liability appears in Tentative Draft No 5, above $\mathrm{n} 9$, at $\mathbb{S} 46$ ( $\mathrm{cmt} \mathrm{l})$. Comment $l$ addresses the fact that other torts (eg, defamation, invasion of privacy and malicious prosecution) 'protect specific aspects of emotional tranquility'. 
risks it); NIED proscribes conduct which shatters a plaintiff's tranquility through inadvertence, inattention or insufficient regard.

This conception of NIED assigns pre-eminence to determinations of duty. The duty not to inflict severe emotional distress carelessly cannot be a general one-owed by everyone to everyone else. Just as everyone does not owe everyone else a duty not to make careless statements, ${ }^{42}$ so too everyone does not-and cannot-owe to everyone else an obligation not to shatter their emotional tranquility carelessly. Every plane crash and indeed every severe car crash might trigger massive liability to those traumatised by the event. ${ }^{43}$ Every emotionally difficult interaction-from ending an intimate personal relationship to firing an employee-would have to be conducted with the utmost delicacy or perhaps avoided entirely. Scope-of-duty questions regarding who owes a legal obligation to exercise reasonable care not to inflict severe emotional harm and to whom they owe that obligation are (on this account of the law) central to NIED doctrine in ways that parallel their centrality to negligent misrepresentation doctrine.

This picture does not correspond to the contours of NIED liability, because in NIED liability the pertinent obligations of conduct are not fixed by the law of NIED. In bystander cases, the pertinent conduct obligation is the obligation to exercise reasonable care to avoid inflicting physical harm. That obligation is grounded in the prospect of reasonably foreseeable physical harm. In pre-existing-relationship cases, NIED liability is grafted onto previously recognised duties of care-duties such as those owed by physicians to patients. Those duties attach to the relationships at hand, but they were grafted onto those relationships by the law long before the prospect of liability for emotional harm was so much as entertained by the law.

The alternative to this 'duty' view is to conceive of liability for NIED as a doctrine delineating the scope of a defendant's liability for breach of a pre-existing duty of care. On this view, severe emotional distress is a form of harm to which liability for breach of a duty grounded on the protection of other interests sometimes extends. Taxonomically speaking, this makes NIED liability a matter of proximate cause, not duty. The Restatement

42 See, eg, Greycas, above n 37, at 1564-65: '[W]hen ... the Supreme Court of Illinois ... held for the first time that negligent misrepresentation [by persons who supply information to others for business purposes] was actionable despite the absence of a contract ... the court was careful to ... limit ... the potential scope of liability'. Elsewhere in the opinion Judge Posner made the following remark about the generally restricted scope of liability for negligent misrepresentation of economically valuable information, ibid, at 1564 (citing W Bishop, 'Negligent Misrepresentation Through Economists' Eyes' (1980) 96 LQR 360). With respect to risks of physical harm, the normal American rule is that everyone does owe everyone else a duty of reasonable care.

43 The Restatement (Third) of Torts, above $\mathrm{n} 13$, at $\mathbb{\$} 47$ (cmt f), aptly observes: ‘[A] negligent airline that causes the death of a beloved celebrity can foresee genuine emotional disturbance on the part of the celebrity's fans, but no court would permit recovery for emotional disturbance under these circumstances'. 
(Third)'s conceptualisation of Dillon illustrates this approach. It views the duty that the defendant breached as a duty to drive carefully, and that duty was predicated on the prospect that negligent driving is likely to cause serious physical harm and even death. ${ }^{44}$ So conceived, liability for NIED in Dillon is not predicated on an obligation to avoid carelessly inflicting emotional distress. What Dillon does is to expand the reach of long-recognised responsibilities to avoid inflicting physical harm. After Dillon, defendants who breach duties of care to avoid inflicting physical harm are exposed to more liability than they were before Dillon was decided. Defendants' liabilities now extend to those who are left physically intact, but emotionally shattered, by the defendants' negligence. ${ }^{45}$

Locating NIED in proximate cause is attractive in part because it slots the doctrine into the element of a negligence claim most conducive to thinking about the proper scope of liability. The chief difficulty presented by liability for negligent infliction of severe emotional distress is that such liability must be carefully bounded. ${ }^{46}$ Bounding liability is the principal task of proximate cause doctrine. Duty doctrine, by contrast, is preoccupied with the question of when conduct ought to be subject to obligation in tort, instead of being parcelled out to contract, property or the domain of legally unregulated conduct. Duty's primary role is to determine the existence of an obligation of care-not to specify when responsibility for harm wrongly inflicted reaches its outer perimeter.

To be sure, this forward-looking claim that proximate cause doctrine is better suited to address the chief problem presented by liability for NIED is not by itself sufficient reason to classify NIED as a proximate cause doctrine and not a duty one. We also need to ask the backward-looking question: Which of these categorisations better fits the cases?

\section{A. Duty or 'Proximate Cause'?}

The interpretive question at the heart of this debate is whether the defendant's obligation of care in NIED cases arises primarily out of the prospect of emotional distress on the part of persons in the plaintiff's position,

44 '[A] bystander's cause of action for negligently inflicted emotional disturbance is derivative of the physically injured person's tort claim against the tortfeasor': Restatement (Third) of Torts, above $\mathrm{n} 13$, at $\$ 47$ ( $\mathrm{cmt} \mathrm{c})$.

45 Dillon, above $\mathrm{n} 1$, at 922 .

46 Tentative Draft No 5, above n 9, at $\mathbb{4} 47$ (reporters' note ( $\mathrm{cmt}$ f)). Many decades ago, when mental tranquility was first being recognised as an interest that tort law should protect, Dean Prosser commented that 'some boundary short of such foreseeability must necessarily be set'. Prosser, above n 18, at 891. Commentators have raised legitimate worries that, if acceptable limits on recovery for emotional harm cannot be fashioned, liability for emotional harm may have to be abolished entirely. See, eg, J Stapleton, 'In Restraint of Tort' in P Birks (ed), The Frontiers of Liability, vol 2 (Oxford, Oxford University Press, 1994) 83, 95-96. 
or primarily out of other concerns. Duty is a protean term in the law of negligence, but its primary meaning has to do with the existence of an obligation in tort-with whether the defendant's conduct is governed by the law of negligence or not. ${ }^{47}$ When we inquire into duty we inquire into the advisability of imposing an obligation of reasonable care on some class of persons, with respect to some class of risks, for the benefit of another class of persons. We consider such possibilities as leaving risk of pure emotional injury legally unregulated, or leaving pure economic loss to the law of contract. ${ }^{48}$ We paint with a broad brush. Broad reflection on the urgency of the interest at issue-the physical integrity of the person, people's legitimate economic expectancies, their claims to emotional tranquility-and the legal protection that the interest at issue is owed, are the order of the day. By contrast, we discriminate when proximate cause judgments about the extent of a defendant's responsibility must be made. We begin from the premise that the defendant has breached an obligation to conduct herself carefully, and ask just how far her responsibility extends. Here, too, we discriminate among interests but our ambition is to draw a circle around the most important harms.

\section{(i) The Generality of Duty}

The canonical negligence duty is the duty not to expose others to an unreasonable risk of physical harm. That duty is both highly general and deeply entrenched in American tort law. The Wisconsin Supreme Court, for example, has proclaimed that 'everyone has a duty of care to the whole world'. ${ }^{49}$ The California Supreme Court, echoing a 130-year-old statute, has remarked that '[i]n this state, the general rule is that all persons have a duty to use ordinary care to prevent others from being injured as the result of their conduct'. 50 The Restatement (Third) states:

$[\mathrm{A}] \mathrm{n}$ actor ordinarily has a duty to exercise reasonable care. That is equivalent to saying that an actor is subject to liability for negligent conduct that causes

47 For discussion, see DA Esper and GC Keating, 'Abusing 'Duty' (2006) 79 Southern California Law Review 265, 273-77. Duty is also used in other senses and, indeed, is sometimes used to address problems that are quite plainly proximate cause problems, ibid, at 288-89. The important question, then, is whether duty in its primary sense exists in NIED cases. After all, Dillon uses the language of duty, and it is clearly concerned with the extent of defendant's liability-not with the existence of its obligation. See below nn 71-73 and accompanying text.

48 See, for example, E River Steamship Corp $v$ Transamerica Delaval Inc 476 US 858, 871-73, 106 S Ct 2295, 2302-2303 (1986).

49 Miller $v$ Wal-Mart Stores, Inc 580 NW 2d 233, 238, 219 Wis 2d 250, 259 (1998).

50 Randi W $v$ Muroc Joint Unified Sch Dist 929 P 2d 582, 588, 14 Cal 4th 1066, 1076 (1997); see also Cal Civ Code $\mathbb{S} 1714$ (a) (originally enacted in 1872, prescribing that everyone owes a duty of ordinary care to everyone else). 
physical harm. Thus, in cases involving physical harm, courts ordinarily need not concern themselves with the existence or content of this ordinary duty. ${ }^{51}$

For their part, commentators have recognised a general duty to exercise reasonable care at least since the time of Oliver Wendell Holmes. ${ }^{52}$ To be sure, recent retrenchment in the law of torts may represent an attempt to shrink the domain of negligence law, but even these developments leave intact a general duty to exercise reasonable care to avoid inflicting physical harm. ${ }^{53}$

\section{(ii) Existence of Obligation Versus Extent of Responsibility}

Proximate cause doctrine, by contrast, picks and chooses among very similar cases, extending and contracting liability in ways that are perennially vulnerable to the charge of being unprincipled. It does so because its chief preoccupation is defining an appropriate orbit of liability-an orbit that is neither so large that it is both unmanageable and disproportionate to the wrong done, nor so small that it is both inadequate as redress for the wrong done and insufficient as an incentive to discharge the duty of due care. Because it performs a role different from the role of duty doctrine, the questions that proximate cause doctrine invites differ from the questions that duty doctrine asks. When we inquire into duty we ask such questions as: is our interest in seeing our physical integrity respected owed the protection of tort law or contract law? Is the same protection owed to our interest in seeing our legitimate economic expectations honoured? When we inquire into proximate cause we ask where do the fair and effective boundaries of responsibility for harm wrongly done lie?

51 Restatement (Third) of Torts: Liability for Physical \& Emotional Harm (Proposed Final Draft No 1) (2005) \$ 6 (cmt f).

52 See White, above n 18, at 12-13, (citing 'The Theory of Torts' (1873) 7 American Law Register 652, an unsigned article all but universally attributed to Holmes). Case law began to recognise the modern duty of due care in the 1830s (ibid, at 15). See also Brown $v$ Kendall 60 Mass 292, 296 (1850) (Shaw CJ). But the duty was not general in the nineteenth century because it was hedged in by property and contract law. See, eg, Farwell v Boston \& Worcester $R R$ Corp 45 Mass 49, 59 (1842) (Shaw CJ) (employer had no duty to take precautions that would protect an employee from injury at the hands of fellow employees); Losee $v$ Clute 51 NY 494, 496-97, 6 Sickels 494 (1873) (manufacturer of a dangerous boiler owed no duty of reasonable care to anyone other than its employees); Thomas $v$ Winchester 6 NY 397, 407-08, 2 Seld 397 (1852) (sellers of goods had no general duty to those with whom they were not in privity of contract); Roberson $v$ Mayor of New York 28 NYS 13, 14, 58 NY St Rep 391 (CP 1894) (landowners owe licensees and trespassers no affirmative duties to keep the premises safe); $R v$ Smith (1826) 2 Car \& P 449, 456, 172 ER 203, 207 (caretakers of a mentally disabled man owed no duty to tend to his health). It was not until the twentieth century that the duty of reasonable care became a highly general legal obligation.

53 See Esper and Keating, above n 47, at 266, 278. 


\section{B. Duty and Proximate Cause in NIED Cases}

The classification of liability for NIED as either duty or proximate cause determines the prism through which we perceive the issues at hand. Inconveniently, however, NIED cases take two different forms and, as a result, does not go gently into either box. These two different forms may be called 'bystander' cases and 'pre-existing-relationship' cases. ${ }^{54}$

Bystander NIED cases are defined by two essential features. First, they involve accidents among strangers. Second, the emotional distress that they address is parasitic on risk of physical injury. ${ }^{55}$ Pre-existing-relationship cases are likewise defined by two essential features. First, the parties to these cases are bound together by a pre-existing relationship, and the emotional distress arises when the defendant fails to discharge some duty integral to that relationship. Second, liability for emotional harm is not parasitic on the prospect of physical harm. ${ }^{56}$ In pre-existing-relationship cases, breach of duty does not endanger anyone physically.

When emotional distress is parasitic on the prospect of physical harm to someone, as in the bystander case, the proximate cause characterisation of NIED clearly fits the cases better than the duty characterisation does. The duty breached is evident and unproblematic; it is the general negligence duty not to put others at unreasonable risk of physical harm. Indeed, duty, breach and cause in fact are all plainly present. The problem is that the harm culpably risked (physical injury) is different from the harm actually inflicted (severe emotional distress). Taxonomically, this hard question is a question of proximate cause; it is a question about the proper scope of liability, not a question about the legal standard to which a defendant must conform his or her conduct.

The second kind of NIED case is more difficult to classify. It is defined by two conditions: (1) the presence of a pre-existing relationship between plaintiff and defendant; and (2) the fact that breach of duty does not usually result in the creation of physical peril. Misdiagnosing a married patient

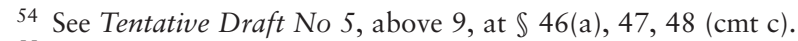

55 The Restatement (Third), above n 13, at $\$ 46$ ( $\mathrm{cmt}$ a), further subdivides bystander cases into smaller categories. In the first of these subcategories, the plaintiff is negligently put at risk of physical harm and fortuitously escapes such harm only to suffer severe emotional distress from his or her physical peril. In the second, physical injury befalls someone else, and the plaintiff seeking recovery for pure emotional harm is a witness to that injury. Cleaving these two kinds of cases apart is, I think, mistaken. Courts extended liability to the second class of cases because the limitation of liability to the first class of cases was perceived to be arbitrary and untenable: Dillon, above n 1, at 915. The limitation is untenable because the two kinds of cases are fundamentally alike. In both kinds of cases physical harm is unreasonably risked but plaintiff suffers only emotional anguish. But see Tentative Draft No 5, above n 9, at $\mathbb{S} 46$ (cmt b).

56 See, eg, Perry-Rogers $v$ Obasaju 723 NYS 2d 28, 29, 282 AD 2d 231 (App Div 2001) (holding that recovery of damages for emotional harm does not depend on suffering physical harm). 
as infected with a venereal disease, cremating a corpse that was meant to be buried, and implanting an embryo created by in vitro fertilisation into the wrong womb are cases in this class. ${ }^{57}$ These are harms that arise in the course of ongoing relationships to which important legal obligations have already attached. The puzzle in this class of cases seems deeper and more difficult than the puzzle presented by bystander cases. Should we say that these cases, too, are proximate cause cases because they are about the extent of liability for breach of an independently established duty of care? Or should we say that these are duty cases because they recognise a freestanding obligation of care with respect to the emotional tranquility of certain classes of persons?

According to the Restatement (Third), the essential question in these cases is whether the emotional distress 'occurs in the course of specified categories of activities, undertakings, or relationships in which negligent conduct is especially likely to cause serious emotional disturbance'. ${ }^{58}$ This may overshoot the mark. Pre-existing relationships are surely essential, and the absence of physical peril is likewise critical, but the role played by the prospect of emotional distress in justifying the imposition of a duty does not appear comparably central.

\section{Why Pre-existing-Relationship Cases Are Proximate Cause Cases}

We should, I think, say that pre-existing-relationship cases are proximate cause cases, albeit unusual ones. From a proximate cause perspective, the peculiarity of the pre-existing-relationship cases lies in the fact that the worry they address is the exact opposite of the worry that animates most of proximate cause doctrine. Proximate cause case law is haunted by the spectre of excessive liability and is therefore preoccupied with placing 'controllable limits on liability'. ${ }^{59}$ This is, indeed, the very worry behind limits on recovery in those NIED cases where the right to recover for emotional

57 See Chizmar v Mackie 896 P 2d 196, 203-5, 63 USLW 2767 (Alaska SC 1995) (defendant doctor could be liable for emotional injury where the doctor negligently misdiagnosed a patient with AIDS); Guth $v$ Freeland 28 P 3d 982, 990, 96 Hawai'i 147, 155 (2001) (defendant morgue had a duty to use reasonable care in handling the plaintiffs' mother); Perry-Rogers, above n 56, at 29-30 (defendant fertility clinic could be liable for emotional harm despite there being no risk of physical harm when the defendant negligently implanted an embryo into the wrong womb).

58 Tentative Draft No 5, above n 9, at $\mathbb{\$} 46(\mathrm{~b})$. Comment $\mathrm{d}$ to $\mathbb{S} 46$ notes that subsection (b) is unlike subsection (a) in that 'recovery under this Subsection does not require that the defendant have created a risk of bodily harm to the plaintiff'. Comment b further specifies the domain of this class of NIED cases by saying that the pre-existing relationship 'line of cases recognizes an exception to the general no-liability rule when an actor undertakes to perform specified obligations, engages in specified activities, or is in a specified relationship fraught with the risk of emotional disturbance'.

59 Straus $v$ Belle Realty Co 482 NE 2d 34, 38, 65 NY 2d 399, 405 (1995). 
distress is parasitic on the culpable imposition of risk of physical harm. Without some arbitrary cut-off, liability for emotional distress might extend indefinitely and therefore excessively. ${ }^{60}$

Pre-existing-relationship NIED cases address an extent-of-liability problem, but the problem they address is not excessive liability: 'When the defendant owes an independent duty of care to the plaintiff, there is no risk of unlimited liability to an unlimited number of people. Liability turns solely on relationships accepted by the defendant, usually under a contractual arrangement'. ${ }^{61}$ The extent-of-liability problem in 'pre-existingrelationship' NIED cases thus turns out to be not too much but too little liability. Precisely because the defendant's failure to discharge its obligations does not result in physical injury to anyone, no liability at all would be the normal result in these cases-unless we recognise liability for NIED. Pre-existing-relationship NIED cases are proximate cause cases-not duty cases-because they are about the extent of the defendant's responsibility for failing to comply with obligations which originate independently of the law of liability for NIED.

Pre-existing-relationship NIED cases thus do not impose new obligations of conduct on anyone. The obligations at issue in pre-existing-relationship NIED cases originate antecedently to-and independently of-the liability recognised by the NIED cases themselves. What the cases do is to expand the set of harms for which certain classes of injurers must bear remedial responsibility when they fail to discharge their pre-existing duties to conduct themselves with reasonable care towards those they have harmed. Preexisting-relationship NIED cases expand liability in important part because they are prompted by the most basic of proximate cause consideration: absent liability for emotional distress, most of these wrongdoers will bear no financial responsibility at all for the harm that they have negligently inflicted. NIED is thus fundamentally different from the tort of negligent misrepresentation as it is conventionally understood. That tort is understood to impose new obligations of conduct. ${ }^{62}$

60 Recall The Restatement (Third)'s observations about the use of arbitrary lines to limit recovery for emotional disturbance as 'recurring (and new) theme' of the emotional distress materials. cf Dillon, above n 1, at 922 (reasoning that the fear of increased litigation will not prevent liability for causing emotional trauma despite not having defined limitations for such liability); D Kennedy, 'The Structure of Blackstone's Commentaries' (1979) 28 Buffalo Law Review 205, 356 ('The rules about the tort of intentional infliction of emotional harm might, if they were enforceable, modify every aspect of private social intercourse').

61 Tentative Draft No 5, above n 9, at $\$ 46$ (reporters' note $(\mathrm{cmt} \mathrm{d})$ ), quoting Dan B Dobbs, The Law of Torts (St Paul, Minn, West Group, 2000) at 849 \$ 312.

62 Recall that Judge Posner in Greycas, above n 37, at 1564-65 noted that 'the Supreme Court of Illinois ... [was holding] for the first time that negligent misrepresentation [by persons who supply information to others for business purposes] was actionable despite the absence of a contract'. The moment that contract-independent obligations were recognised was the moment when the tort of negligent misrepresentation came into existence in Illinois, as far as 
If this analysis is correct, it teaches a surprising lesson. The expansion of liability for mental suffering is correctly believed to be one of the preeminent examples of tort law's expansion over the course of the twentieth century. Nonetheless, modern negligence law has not insisted that people conduct themselves differently, it has merely expanded their responsibility for emotional harm when they fail to discharge their pre-existing obligations of care. In proceeding this way, tort law has placed itself on solid ground. The principle of reasonable foreseeability of harm that is the touchstone of duty in general proves too much when emotional distress is at issue. Or so I shall now argue.

\section{WHY THERE IS NO GENERAL DUTY NOT TO INFLICT EMOTIONAL ANGUISH}

Dillon, the most important modern American NIED case, instructed California courts to determine whether a defendant 'owe[d a] plaintiff a duty of due care' by deciding 'whether the accident and harm was reasonably foreseeable'. ${ }^{63}$ That inquiry into reasonable foreseeability was to be guided by giving special weight to: (1) the plaintiff's proximity to the accident; (2) whether or not the accident resulted from the direct emotional impact of witnessing the accident; and (3) whether or not the plaintiff and the victim were closely related. ${ }^{64}$

In taking reasonable foreseeability of emotional harm to be the basic criterion triggering a duty to exercise due care to avoid inflicting emotional harm, Dillon appears to complete two of the most important developments in twentieth-century tort law. One development was the steady expansion of liability for emotional distress. For the better part of a century, emotional harm had been working first to be recognised and then to be freed from the shadow of physical harm. Dillon recognised emotional integrity as an independent interest fully worthy of protection in its own right. The other development was the triumph of reasonable foreseeability of harm as the master principle of duty in negligence law. Nineteenth-century tort law recognised reasonable foreseeability of harm as the touchstone of duty in negligence law, ${ }^{65}$ but hemmed negligence law in, both with rules of 'no duty' and by subordinating tort to property and contract.

the provision of business information to third persons was concerned. The imposition of new obligations is the essence of the matter. Duty is the essence of the doctrine.

63 Above n 1, at 920-21. For a clear example of a court adopting a duty interpretation of Dillon see Molien v Kaiser Foundation Hospitals 616 P 2d 813, 814, 27 Cal 3d 916, 918 (1980).

64 Dillon, above n 1, at 920.

65 See, eg, Blyth v Birmingham Waterworks (1856) 11 Ex Ch 781, 156 ER 1047. 
Nineteenth-century tort law parcelled out some harms-pre-eminently, emotional ones-to the domain of 'no duty'. It parcelled other reasonably foreseeable harms out to contract or property. Product and workplace accidents were handed off to contract and the obligations of landowners and occupiers to entrants onto their real property were assigned to property law. Contract law, for its part, made 'no duty' the reigning rule for product and workplace accidents. Although property law specified duties, it determined those duties not by reference to reasonable foreseeability, but by reference to its own status categories. ${ }^{66}$ Tort was thus the servant of property.

Sixteen years into the twentieth century, Cardozo J disposed of the privity limitation on product liability claims by proclaiming that reasonable foreseeability of harm sufficed to create an obligation in tort. ${ }^{67} \mathrm{~A}$ decade later-in a passage quoted by Dillon ${ }^{68}$ —Cardozo J asserted that reasonable foreseeability of harm was the master test of the scope of duty and therefore the key to scope of liability (or proximate cause). Forty years after Palsgraf, the California Supreme Court sought to complete Cardozo J's project. Rowland $v$ Christian, ${ }^{69}$ decided the very same year as Dillon, swept aside the status categories and made reasonable foreseeability of harm the touchstone of the liability of owners and occupiers of land to entrants onto their property. Dillon did the same thing for pure emotional harm, declaring 'no duty' dead and asserting that, henceforth, reasonable foreseeability of emotional harm would give rise to a duty to avoid carelessly inflicting such harm.

Except that it did not. As we have seen, in what must be one of legal history's larger ironies, Dillon's trumpeting of the triumph of reasonable foreseeability heralded the end of reasonable foreseeability's rise as the master principle of negligence law. Twenty years after it decided Dillon, the California Supreme Court repudiated reasonable foreseeability of emotional distress as the measure of responsibility for such distress. ${ }^{70}$ Mental suffering is endemic. A general duty to exercise reasonable care not to inflict emotional distress on others would be almost literally unbearable-even

66 See R Rabin, 'The Historical Development of the Fault Principle: A Reinterpretation' (1981) 15 Georgia Law Review 925, 933-36 (stressing, in particular, the importance of rules of 'no duty'); see also Esper and Keating, above n 47, at 277-78.

67 MacPherson, above n 2, at 390: '[T] known use, makes vigilance a duty. We have put aside the notion that the duty to safeguard life and limb, when the consequences of negligence may be foreseen, grows out of contract and nothing else. We have put the source of obligation where it ought to be. We have put its source in the law.'

68 Palsgraf, above $\mathrm{n} 4$, at 344: 'The risk reasonably to be perceived defines the duty to be obeyed' (quoted by Dillon, above n 1, at 919).

69 Above $n 6$.

70 See above $\mathrm{n} 33$ and accompanying text. 
if the distress involved were limited to severe emotional distress. It would 'modify every aspect of private social intercourse'. ${ }^{71}$

In fact, even a general obligation not to inflict intentional emotional distress is starkly implausible:

To properly manage its business, an employer must be able to supervise, review, criticize, demote, transfer, and discipline employees. Although many of these acts are necessarily unpleasant for the employee, an employer must have latitude to exercise these rights in a permissible way, even though emotional distress results. ${ }^{72}$

Personal life is at least as fraught as professional life with intensely distressing actions. If we are to have religious practices like shunning and marital practices like divorce, we must be prepared to accept the intentional infliction of severe emotional distress. ${ }^{73}$ 'I don't love you anymore' can be an unbearably painful statement. Even the tort of IIED must be sharply cabined — as it is by the requirement that the distress result from 'outrageous' conduct-if we are to preserve liberties we prize.

We must be at liberty to distress others-and severely —if we are to be free not just to break off intimate personal relations and to practice our religious convictions but also to have extramarital affairs and abortions, to express our political opinions and to discredit witnesses who may well be telling the truth. ${ }^{74}$ Indeed, simply insisting on one's rights can inflict

71 Kennedy, above n 60, at 356. Kennedy's primary target here is jurisprudential. He is out to shatter the comfortable assumption that legal norms have some natural extension. We tend to think that the Equal Protection Clause harbours great critical power, but that the law of torts does not. The Equal Protection Clause can upend deeply entrenched social practices such as segregated public education, but the tort of IIED and NIED doctrine can merely nibble around the edges of our social lives. Kennedy's point is that, let loose, the tort norms protecting emotional tranquility could upend industrial civilisation itself.

72 GTE Sw, Inc v Bruce 998 SW 2d 605, 612 (Tex SC 1999).

73 See, eg, Paul $v$ Watchtower Bible \& Tract Soc'y 819 F 2d 875, 879, 883-84, 93 ALR Fed 737 (9th Cir 1987) (holding that the Jehovah's Witnesses' practice of shunning is 'privileged' conduct); Whelan $v$ Whelan 588 A 2d 251, 252, 41 Conn Supp 519, 520 (1991) ('[V] irtually all dissolutions of marriage involve the infliction of emotional distress. For the tort of intentional infliction of emotional distress to be established ... the plaintiff must allege and prove conduct considerably more egregious than that experienced in the rough and tumble of everyday life or, for that matter, the everyday dissolution of marriage').

74 See Browning $v$ Browning 584 SW 2d 406 (Ky CA 1979) (extramarital affair); Przybyla $v$ Przybla 87 Wis 2d 441, 275 NW 2d 112 (1978) (abortion); Hustler Magazine, Inc v Falwell 485 US 46 (1988) (holding that a magazine parody of a celebrity constituted constitutionally protected free-speech and therefore any damages to the celebrity were not compensable); Snyder v Phelps 131 S Ct 1207 (2011) (holding that picketing at a service member's funeral was entitled to special protection under the First Amendment). It has been forcefully argued that cross-examining a witness one believes to be telling the truth is an ethical obligation of defence counsel in a criminal case. See M Freedman, 'The Professional Responsibility of the Criminal Defense Lawyer: the Three Hardest Questions' (1966) 64 Michigan Law Review 1469, 1474-76. Clearly, such cross-examination is immunised from tort liability. See Restatement (Second) of Torts (1979) \$586; WP Keeton (ed), Prosser and Keeton on Torts, 5th edn (St Paul, Minn, West Group, 1984) \$114. 
severe emotional distress. Litigation, for example, is usually unpleasant and deliberately so. Insisting on one's rights and nothing more, however, cannot be tortious. ${ }^{75}$ The consequence of these facts is that the tort of IIED has never provided the kind of general protection of the interest in emotional tranquility that it appears to promise:

There are simply a large number of situations in which intentionally making others uncomfortable, unhappy, and upset is viewed as justified either in pursuit of one's legal rights (eg, debt collection) or in service of a greater social good (eg, cross-examination at trial) of the person's 'own good' (eg, basic training). ${ }^{76}$

Within the law of torts, IIED is 'unique in denying recovery to people who have suffered intentional, unjustifiable, and severe injuries to [the] interest-emotional tranquility-that the [tort] purports to protect' ${ }^{77}$ In practice, the tort of IIED protects primarily against a small slice of emotionally distressing conduct, namely, conduct which precipitates severe emotional distress by exploiting a position of power, abusing authority, or deliberately and coercively disregarding a plaintiff's rights. ${ }^{78}$ The principal reason why the tort does not provide the general protection of emotional tranquility it appears to offer is that the consequences of providing such general protection of emotional tranquility for our social lives are simply unacceptable.

A general duty not to inflict emotional distress negligently would be even more stifling than an expansive interpretation of the tort of IIED. If we were to prohibit the negligent infliction of emotional distress, it is not clear that we could continue to conduct many ordinary activities. Industrial life is a horror, an endless source of psychological trauma. That, indeed, is the Rousseauian insight at the heart of Professor Kennedy's observation. ${ }^{79}$ You do not have to be neurasthenic to feel the force of the point. Many ordinary activities-like flying planes or driving cars-inevitably inflict violent and horrifying harms. Automobile accidents are capable not just of snuffing out small children's lives, but also of paralysing, disfiguring, dismembering, maiming and immolating people. They do so every day.

The small scale of an ordinary automobile accident, moreover, does not capture the fears and horrors to which modern technology gives rise. Ordinary plane crashes are quite capable of ending hundreds of lives in split seconds of terror. ${ }^{80}$ Witnessing even ordinary accidents can be

\footnotetext{
75 Davis v Currier 704 A 2d 1207, 1997 ME 199 (SJC 1997); FDIC v S Prawer \& Co 829 F Supp 439, 449 (D Me 1993).

76 D Givelber, 'The Right to Minimum Social Decency and the Limits of Evenhandedness: Intentional Infliction of Emotional Distress by Outrageous Conduct' (1982) 82 Columbia Law Review 42, 57.

77 Ibid, at 54.

78 Ibid, passim.

79 Kennedy, above n 60, at 356.

80 Hollywood knows as much. See the film Fearless (1993).
} 
horrifying and traumatic and, in an age of television, we may all become unwilling witnesses to such horrors. ${ }^{81}$ Famous accidents, from the Titanic to the Challenger, haunt our collective memory. These catastrophes bear witness to the reality that essential modern activities harness the enormous destructive power of advanced technology. We need the activities and, therefore, we must generally bear the distress they cause when they go awry. Taken seriously, a general obligation not to inflict emotional distress negligently would require us to remake our world into a pastoral idyll.

The unacceptability of a general duty not to inflict reasonably avoidable emotional distress is not-as conventional wisdom would have $\mathrm{it}^{82}$-the fatal flaw corrupting the entire edifice of NIED liability. On the contrary, the entire architecture of contemporary American NIED liability is constructed to preclude the imposition of an utterly implausible general duty. The reconceptualisation of NIED as scope of responsibility frees courts from having to decide when the prospect of emotional distress is sufficient to impose a freestanding obligation to avoid inflicting such distress, but it obligates courts to decide when liability for breach of independent duty should extend to encompass the infliction of emotional injury.

That inquiry has two aspects. The first is fixing the overall scope of liability so that it is neither insufficient nor excessive. The second involves discriminating among instances of emotional distress and determining which to include and which to exclude. Courts and commentators have a handle on the first aspect, but are largely defeated by the second. Recall the Restatement (Third)'s candid observation that determining the proper limits of recovery for emotional distress requires making 'use of arbitrary lines to limit recovery'. ${ }^{83}$ That theme emerges because lines which are not arbitrary are nowhere to be found. The master principle governing discrimination among instances of emotional distress is thus simply the principle that lines must be drawn somewhere.

Lines do indeed need to be drawn somewhere and they must be drawn arbitrarily if they cannot be drawn in any more principled way. Nevertheless, the law of NIED would be better if it drew principled distinctions among instances of emotional harm instead of arbitrary ones. Arbitrary distinctions are unfortunate because they leave the law with very little to say about why the power of the state should be used to require wrongdoers to repair some

81 Recall the remark in the Restatement (Third) of Torts $\$ 47$ ( $\mathrm{cmt} \mathrm{f),} \mathrm{quoted} \mathrm{above} \mathrm{n} 43$, on the distress that might be caused by a single airplane crash which kills a beloved celebrity. Of course, the non-accidental horror of 9/11, the Challenger disaster, and the Kennedy assassination haunt our imaginations even more.

82 As Goldberg and Zipursky, for one, believe, as demonstrated in their plenary address at the Obligations VI Conference, above n 22. One may, of course, argue that this solution is a failure because the correct conception of duty makes it clear that NIED liability is predicated on an untenable conception of duty. That, however, is not an internal problem.

83 Tentative Draft No 5, above n 9, at xxi. 
instances of emotional distress and not others. The difficulty that NIED liability needs to surmount, then, is not how to determine when the prospect of emotional distress justifies the imposition of an independent obligation of care, but how to distinguish among more and less severe instances of emotional distress. The problem is to sort 'losses' from 'harms'.

\section{NIED AS PROXIMATE CAUSE: DETERMINING THE SCOPE OF RESPONSIBILITY}

The deep difficulty with which courts struggle is whether and when emotional suffering is a form of harm. Seriousness or urgency surely plays a role here: emotional trauma is one thing, 'hurt feelings' are another. ${ }^{84}$ The pervasiveness of 'normal' emotional suffering is also relevant. A substantial amount of severe distress-think of the distress that parents experience from the premature death of a child even when natural causes alone are implicated-is simply part of the normal background of emotional distress that accompanies much of ordinary life. Pervasive emotional distress cannot be the predicate of NIED liability, no matter how severe it is. Here, proximate cause determinations with respect to liability for pure emotional harm parallel proximate cause determinations with respect to liability for pure economic loss. The economic loss or emotional distress must be special in some way, distinct from the normal background of loss and suffering that goes unredressed. ${ }^{85}$

These two conditions, however, do not reach the heart of the matter. The law of negligence is a law of responsibility for harm wrongly done. ${ }^{86}$ Canonically, harm in the law of torts has meant 'physical harm', in contradistinction both to pure economic loss and pure emotional harm. On the one hand, the expansion of tort liability to encompass some pure emotional distress is rooted in the perception that some such distress is harm. Courts perceive the emotional distress that a mother who witnesses the negligent death of her child suffers as a 'traumatic effect', not a 'hurt feeling'. Traumas leave scars on their victims, impairing their psyches and their lives.

\footnotetext{
84 Compare Thing, above n 8, at 823 (referring to the 'emotional trauma' that a mother who witnesses the negligent harming of her child experiences) with Clark, above n 19, at 64 ("'He intentionally hurt my feelings" does not yet sound in tort').

85 Compare In re One Meridian Plaza Fire Litigation 820 F Supp 1460, 1480 (ED Pa 1993) (explaining and applying the 'peculiar harm' rule of public nuisance law) with Thing, above n 8 , at 829 .

86 Although she is not concerned with 'harm' as a morally distinctive category, Professor Jane Stapleton makes a closely related point when she writes, 'It is a truism that a fundamental requirement for a claim in negligence is that the plaintiff has suffered some past "damage." A breach of duty by the defendant is not enough. The cause of action will not accrue until actionable damage occurs. This damage is said to form the gist of the action': J Stapleton, 'The Gist of Negligence: Part I' (1988) 104 LQR 213, 213.
} 
Parents who suffer the death of a child are never quite the same. On the other hand, the law's pervasive uncertainty about how far to extend liability for the negligent infliction of pure emotional injury is rooted in the recognition that not all distress counts as serious harm-and, more proximately, in the difficulty of determining when emotional distress ceases to be harm.

\section{A. Harm and Emotional Distress}

Harm matters. Like killing, ${ }^{87}$ harm is a subject of special and intrinsic moral concern. Its avoidance has special priority-benefitting others is not a comparably urgent obligation-and its infliction presumptively marks a fundamental boundary to individual liberty. '[T]he only purpose', John Stuart Mill famously insisted, 'for which power can be rightfully exercised over any member of a civilized community, against his will, is to prevent harm to others' ${ }^{88}$ Just what accounts for harm's moral significance and priority is a matter of enduring dispute. ${ }^{89}$ The best answer, I think, is that harm is an assault on autonomy because harm impairs and, at the limit, negates our agency. Harms rob of us of normal and essential powers through which we act and work our wills in the world.

To be harmed is to be put, as the Restatements say, in an 'impaired condition'. Harm is detrimental, a change of condition for the worse. Tellingly, harm makes victims of those it afflicts. We suffer harm. With rare exceptions, the harms that we experience are done to us and not by us. What we suffer is injury to our agency since harms thwart our capacity to exert our wills. They mar our mastery over ourselves and our experiences, and they prejudice our efforts to make the world answer to our wills. ${ }^{90}$ Physical

87 The analogy is drawn by Shiffrin, above n 14, at 359 .

88 JS Mill, On Liberty (D Bromwich \& G Kateb (eds)) (New Haven, Yale University Press, 2003) 80.

89 There are three competing accounts of harm in the literature. The most influential account asserts that harms are setbacks to interests. See, eg, J Feinberg, Freedom and Fulfillment: Philosophical Essays, (Princeton, Princeton University Press, 1992) 3-4. A second account argues that they are events that it is bad to suffer. See, eg, M Hanser, 'The Metaphysics of Harm' (2008) 77 Philosophy and Phenomenological Research 421. I am casting my lot with a third view, which asserts harms impose conditions which are bad for those who suffer them because the conditions involve the impairment of agency. For a conception along these lines, see S Shiffrin, 'Wrongful Life, Procreative Responsibility, and the Significance of Harm' (1999) 5 Legal Theory 117, 123-24. Professor Shiffrin's ideas are developed further in 'Harm and its Moral Significance', above n 14. As the text indicates, the idea that harm is linked (negatively) to autonomy goes back at least as far as Mill. In our time, it is carried forward by the work of Joseph Raz and Judith Thomson, as well as by Shiffrin's work. See J Raz, The Morality of Freedom (Oxford, Oxford University Press, 1986) 412-24; Thompson, above n 16, at 227-48. This conception dovetails with tort law's conception of harm as impairment. For our purposes, that convergence is sufficient warrant for the conception.

90 Shiffrin describes the unifying characteristic of harm as an impairment of agency by saying 'harm involves conditions that generate a significant chasm or conflict between one's will and one's experience': 'Wrongful Life', above n 89, at 123. 
harms-broken bones, severed limbs, disabilities of sight and hearing, diseased organs and disfigured body parts-all compromise physical capacities through which we act. Those physical capacities play central, foundational roles in normal human lives. In its core forms-physical injury or pain, illness, disability and death-harm is severe and debilitating. As long as the conditions that they impose persist, core harms seriously debilitate our capacities to act.

Emotional distress 'may be fully as severe and debilitating as physical harm'. ${ }^{91}$ That, of course, is the simplest and best reason to recognise liability for emotional harm. But matters are not quite so simple. Emotional distress differs from physical harm in a fundamental and categorical way. Our emotional reactions are mediated by our minds. Emotional injury may thus be the product-not the negation-of our agency. Often, emotional reactions are much more subject than physical responses to our minds, our wills and our control. We can teach ourselves to toughen up and not be so sensitive, and we can steel ourselves against even exceedingly unpleasant experiences. Our sensibilities are subject to shaping by our wills. The way that we $d o$ react can be made responsive to our considered judgments about how we should react. Up to a point, we can and do learn to protect ourselves against emotional harm by mastering our emotions. We can learn to treat even the most exasperating events of ordinary life with relative calm, and usually do. We learn to cope, not complain.

Judith Thomson's felicitous term 'belief-mediated distress' 92 helps to isolate just why some emotional distress is not really harm. Some emotional distress arises in ways which people experience as visceral and essentially physical. We are overcome by fear or nausea or dizziness at the scene of a grisly accident. ${ }^{93}$ Other emotional distress-much anxiety, offence, fear and anguish - arises because we hold certain beliefs, attitudes or values. My fastidious sense of cleanliness and hygiene may, for instance, cause me to be revolted by the mere sight of a dead fly in the bottled water you propose to serve to me, leaving me anxious, depressed and phobic for months. ${ }^{94}$ Beliefmediated distress arises as much from exercise of the agency of those who experience the distress as it does from the events that precipitate the reaction. We may well want to say that persons who experience belief-mediated

91 Molien v Kaiser Foundation Hospitals 616 P 2d 813, 814, 167 Cal Rptr 831, 832 (1980) (making a case for recovery for pure emotional distress on the ground that it can be as severe and debilitating as physical injury).

92 Above $\mathrm{n} \mathrm{16}$, at 250-51, 253-59. To an important extent, Thomson is thinking about 'offence' cases in contradistinction to 'harm' ones.

93 The early cases permitting recovery for emotional distress are cases where the distress had just this kind of an immediate, visceral, physical quality. See above n 28 and accompanying text.

94 For facts along these lines and a finding of no liability, see Mustapha $v$ Culligan of Canada Ltd 2008 SCC 27, [2008] 2 SCR 114. 
distress are themselves responsible for that distress and we may even be prepared to call them wrong as well as responsible. Delicate sensibilities and irrational beliefs cannot be allowed to fix the boundaries of equal right.

Irrational fear is a useful, and ancient, case in point. I do not have a claim of assault just because I experience fear of imminent physical impact when you glance in my direction. And I surely do not a have a right to defend myself against your glances with physical force. Only a reasonable apprehension of imminent bodily harm will support a claim of assault, no matter how much I may suffer from my belief that your glance threatens me with mayhem. ${ }^{95}$ Irrational fears and irrational mental states do not give rise to any claims that others avoid inflicting them. They are, in fact, not harms at all, a fact Thomson thinks is shown precisely by the fact that they do not give rise to claims that others avoid inflicting them.

Irrational distress is not the only distress that does not count as harm. Offence cases can be as clear as assault cases, at least at common law. The hideous pink flamingo in my front yard may offend my neighbour's aesthetic sensibilities enormously, but it does not give rise to a nuisance claim in tort. ${ }^{96} \mathrm{My}$ eyesore is not an unreasonable interference with the use of your property. The distress it causes is charged to your account. So, too, we are free to dress and decorate in ways that displease our neighbours. The law cannot and does not count the reasonable assertion of rights and privileges as 'harm'. The role of belief in mediating distress is critical here. We can be asked and expected to toughen up and live with each other's bad taste. Stenches and smells are another matter. Their assaults on our senses are visceral and overwhelming and their infliction does count as harm. ${ }^{97}$

Tellingly, the emotional harm for which the law of NIED allows recovery is harm that we either cannot or should not steel ourselves against. Parents are not supposed to steel themselves against the kind of emotional agony they suffer when they witness the accidental death of their child at the hands of a careless driver. The reaction is anything but unduly sensitive. Indeed, we would regard a parent who was indifferent to such an event as appalling. The agony arises out of an appropriate emotional attachment and vulnerability. To protect oneself against such harm by cultivating an indifference to one's child would be deeply disturbing and, indeed, inhuman. A parent who has the kind of attachment to her child that we regard as fitting and valuable will be emotionally devastated by witnessing

95 You cannot, however, exploit someone's special or irrational sensitivity. See, eg, Clark, above n 19, at 66; Dawson v Associates Financial Services Company of Kansas 529 P 2d 104, 215 Kan 814 (1974) (creditor-defendant's knowledge of debtor-plaintiff's peculiar sensibility to emotional harm due to disease made creditor's conduct outrageous).

96 Even severe harms can fail to count as nuisances when they are products of idiosyncratic sensibilities. See Rogers $v$ Elliott 15 NE 768, 146 Mass 349 (1888) (plaintiff who suffered convulsions at the ringing of church bells did not have a nuisance claim).

97 See, eg, O’Cain v O’Cain 322 SC 551, 473 SE 2d 460 (1996). 
the child's sudden death at the hands of someone's negligence. Deep attachments bring deep vulnerabilities.

The loss suffered by the parent is, moreover, permanent and fundamental as well as emotionally deep. In the blink of an eye, the sudden death of a child severs fundamental emotional bonds and ends a relationship central to the parent's life. It destroys completely a project which is a central expression of the parent's agency. It inflicts the anguish of having utterly failed in what may be the most fundamental responsibility of parenthood: protecting from harm the vulnerable being for which you are responsible:

Once she was born I was never not afraid. I was afraid of swimming pools, hightension wires, lye under the sink, aspirin in the medicine cabinet ... I was afraid of rattlesnakes, riptides, landslides, strangers who appeared at the door, unexplained fevers, elevators without operators and empty hotel corridors. The source of the fear was obvious: it was the harm that could come to her. ${ }^{98}$

Margery Dillon's life was impaired in ways which cut deep and could not be repaired. Her distress both constituted harm and marked the infliction of other harm. It constituted harm because normal parental suffering in her circumstance can be paralysing and beyond mastery. It marked the infliction of other harm because the death of her daughter permanently diminished the possibilities open to her life, and forced upon her an unwelcome end to one of her life's most important projects. Her life was altered permanently for the worse in ways that could not be repaired.

Deep vulnerability born of deep and justified attachment likewise marks other cases where liability for NIED is recognised. We think it emotionally wrong for parents to be indifferent to which infant they acquire at the end of an in vitro fertilisation process, or to the fate of a being that they have brought into the world. 'I would like a child and they are all interchangeable as far as I'm concerned' would be an off-putting remark at best. It is, moreover, morally right to care about a being one has brought into the world and morally right to want to assume a large measure of responsibility for the well-being of a human being that one has created. ${ }^{99}$ Perhaps we should get over endowing our coffee mugs with special significance just because we own them, but we should not get over developing attachments to, appreciation of, and responsibility towards our offspring.

This characteristic of the emotional distress to which liability extends in the parenting cases-that it arises out of worthy emotional attachments and vulnerabilities-is a general characteristic of the emotional distress to which NIED liability extends. We do not regard emotional distress at a mortician's botching of the burial of one's loved ones as the kind of hurt feeling that grown people get over. We believe, on the contrary, that people may rightly experience enduring guilt and shame over their perceived failure to

98 Didion, above n 33, at 54.

99 See Shiffrin 'Wrongful Life', above n 89, at 140, 145. 
discharge an important moral obligation and that they are understandably emotionally fragile in the wake of a loved one's death. Nor do we regard severe post-traumatic stress suffered as a result of 'serving as a rescuer at a gruesome train wreck' as the slightly pathetic reaction of a delicate sensibility that needs to be hammered into tougher stuff. ${ }^{100}$ We have ample reason to believe that people may not be able to steel themselves against such horrors and good reason to be grateful that we do not live among the kind of beings who are emotionally untroubled by prolonged exposure to gruesome injury and intense human agony.

In these canonical cases of recovery for NIED, emotional distress has the characteristic of not being something people should be expected to master or to suffer uncomplainingly. Moreover, in part because these are emotional harms against which we are not expected to steel ourselves, the occurrence of these harms is even more likely to be experienced as a visceral and devastating assault on the self. Witnessing the violent death of one's child is the kind of horror that most of us hope never to have to endure. We will have cultivated our vulnerability and our minds will exacerbate our agony. In cases like these, emotional distress both marks and constitutes conditions which resemble serious physical harm in both the brutality of their impact and the permanence of the effect. Parents who suffer the deaths of their children are rarely the same. Part of the parent dies with the child. These facts reinforce the intuition that liability for some emotional harm ought to have a secure place in our law. Some emotional harm is every bit as devastating as physical harm.

That said, the present state of the law of NIED is unsatisfying. The case for extending liability to some belief-mediated emotional distress is that some such distress is as harmful as physical injury. Properly constructed, NIED liability would discriminate qualitatively among instances of emotional distress. It would sort those that are properly classified as 'harm' from those that are properly classified as 'loss'. Neither the lines that Thing draws to cabin Dillon nor the Restatement (Third)'s embrace of arbitrariness provide much comfort in this regard. The lines now being drawn under Thing and the Restatement (Third) are exposed to more or less the same charge of arbitrariness that Dillon levelled against the 'zone of danger' rule. Thing's authorisation of recovery for parents who witness the infliction of serious physical harm on their children and its denial of recovery for parents who merely learn secondhand that their children have been seriously injured marks a qualitative distinction, but a slender one. No one would, I think, argue that parents should steel themselves against learning secondhand of the deaths of their children.

100 Dillon, above n 1, at 923 (citing Chadwick v British Rys Bd [1967] 1 WLR 912, [1967] 2 All ER 945 (QB) (Waller J)). 


\section{B. When is Emotional Distress Harm?}

Thing and the Restatement (Third) rest their respective justifications for arbitrary line drawing on the claim that no plausible principle for discriminating among instances of emotional distress can be found. This is unpersuasive. The NIED cases themselves discriminate in a principled way. They extend liability only to distress for which we do not regard the victims themselves as responsible by virtue of the exercise of their own agency, or against which we do not think people should simply toughen their hides. The concept of 'harm', moreover, can do more work than it is presently being made to do. To be harmed is to be put in an impaired condition. Core harms deprive those they afflict of normal powers of human agency, for as long as the afflictions last. Those powers play central roles in normal human lives. They are both constitutive of, and instrumental to, our ability to express and implement our wills. They are therefore central to our freedom.

Put differently, physical integrity and health are platforms which enable persons to construct their lives. When they are seriously compromised, people are disabled from doing so. These conditions are not necessarily distinguished from 'losses' by their welfare effects. Human adaptability being what it is, the welfare effects of various harms are both uncertain and at least partially subject to determination by those who suffer the conditions. The necessary effect of core harms, however, is to impair the agency of those who are subject to them. Canonical cases of loss do not entail impairment.

When we move away from the core, the relation of harm to agency is more subtle. Some harms do not impair our powers of agency themselves, but do destroy projects and relationships in which our agency is deeply and irreversibly invested. They impair our lives and our lives are the expression of our agency. Our autonomy cannot remain merely a matter of capacities and potentialities. Agency exists to be exercised. It is given expression and comes to fruition in our lives, our relationships and our projects. Some relationships and some projects constitute investments of agency so deep that their destruction is an impairment of our lives and thus a severe blow to our agency even if our basic capacities are left intact. Some harms destroy the person that we were and force us to reconstitute ourselves as new persons with new lives-if we can. The psychic harm of having a fundamental life project destroyed may leave us too wounded to build a new life. This may have been the fate of Margery Dillon. The death of her child brought a premature, brutal and irreparable end to a relationship and a project at the centre of her life; it inflicted a psychic wound that is unlikely ever to heal. The blow is surely shattering enough to alter the course of her life profoundly and involuntarily. All that she can do is to memorialise her child and to build a new life. 
Let us retrace our steps a bit. The fundamental reason why tort law is right to embrace liability for some emotional distress is that psychological integrity is as essential to effective agency as physical integrity is. Core psychological harms impair their victims' psychological integrity, thereby diminishing their agency and the possibilities available in their lives. Childhood sexual abuse, for example, commonly does lasting psychological damage by impairing the capacity to trust. It thereby impairs the capacity to form normal, healthy, lasting human relationships. Post-traumatic stress disorder and clinical depression are likewise conditions that impair the agency of those they afflict. Instructively, the English law of NIED makes 'psychiatric injury' a central criterion of liability. While the phrase is subject to interpretation, it suggests a strong link between NIED liability and the creation of psychological conditions which are plainly harms because they are conditions where the psychological integrity of the victims is compromised and their normal capacities are seriously diminished. The challenge confronting American law-whose criterion of emotional harm is summarised by the Restatement (Third) with the rather vague phrase 'serious emotional disturbance'-is to tie that criterion to the presence of an 'impaired condition'.

The problem, of course, is that emotional distress radiates out in concentric circles from core cases such as chronic impairment of the capacity to trust caused by childhood abuse, through deep grief and serious distress, to ordinary sorrow and upset. As we move further away from the core, harm shades imperceptibly into loss. Saying precisely when harm becomes loss may indeed be impossible: the relevant concepts are not sufficiently sharp and the relevant conditions may blur imperceptibly into one another. Even so, the concept of an 'impaired condition' can help us to sort cases in a principled way. We can ask when and why the suffering of emotional distress is either the mark of an 'impaired condition' or an 'impaired condition' itself. Emotional distress is itself harm when it is acute enough to impair our wills; the longer that impairment lasts the worse the harm is. Emotional distress marks (and perhaps exacerbates) harm when it is the normal reaction to suffering a serious harm. Here, emotional distress seems to identify a distinct domain of essentially objective harm: there are losses which impair the lives of those who suffer them so seriously that emotional anguish is the natural response to such loss.

The premature death of a child once again is a useful case in point. At the limit, the death of a child can cause incapacitating grief, the kind of grief that is as disabling as a significant physical impairment. In the normal case, the death of a child results not in incapacitating grief, but in a wound from which its victims do not fully recover. The possibilities available in their lives are profoundly and irreparably impaired. This, too, is harm-the permanent and profound diminution of the parent's agency-even though 
this particular harm is not itself essentially experiential. ${ }^{101}$ There is a paradox here. Liability for emotional distress has at its centre harms which are quintessentially subjective and experiential—emotional states so powerful that they overwhelm our normal capacities for self-governance. Yet liability extends to cases where emotional distress is merely the marker for deeply objective harm-harms whose essence lies in possibilities permanently foreclosed, experiences which will never be had. Tellingly, the law of torts counts death a harm, indeed, the pre-eminent harm, even though the condition of being dead is not experienced. Death ends agency and forecloses possibilities that were previously available within a life. These are harms even if the possibilities lost are never experienced. The parent of a child who is wrongfully killed also has his or her life permanently diminished. It is no longer possible for a parent to live the same life, experience the particular goods of raising that child. Nor is it possible to leave the same legacy or make the same contribution to the world. A child's death forces a particular end to one of the parent's most central relationships and destroys the fruits of what is normally a deep investment of agency. Even when parents are not incapacitated by grief they are reduced to all but utter helplessness by the wrongful death of a child.

Most of the wrongs to which the American law of NIED responds under the guise of serious emotional disturbance thwart in serious ways the wills-and severely and irreversibly diminish the lives-of those they disturb. Mistakenly handing a child over to the wrong parents significantly impairs the relations between parent and child unless it is remedied immediately. It forces the painful end of attachments that have been formed and profoundly affects the formation of new attachments. Mishandling a corpse permanently prevents close family members from discharging a significant obligation to the dead and puts their relations with the deceased wrong in a way which cannot be repaired. That enduring condition is fairly regarded as a harm.

The Restatement (Third) is therefore wrong to throw up its hands and insist that the only lines that can be drawn are arbitrary ones. Significant sorting of cases of emotional distress can be done by asking which cases involve impairment, which do not, and how serious the impairments are. In that respect, Thing's insistence on arbitrariness is telling self-criticism: the distinction between witnessing the negligent death of one's child and learning of it over the phone probably does not mark a major difference in the harm suffered. The distinction between close family members (functionally conceived) and strangers who happen to witness the horror at hand,

101 The literature on death shows, I think, that the contents of one's life exceed the boundaries of one's experience. See, eg, T Nagel, 'Death' in his Mortal Questions (Cambridge, Cambridge University Press, 1979). Death is probably a harm even though it is not really experienced. 
by contrast, is a distinction that marks a fundamental difference in harm suffered. It is both wholly possible and desirable for the law of NIED to draw more distinctions like the latter and fewer like the former.

\section{REFINING RECOVERY FOR NIED}

Contemporary American law for NIED is a curious case. Its broad outlines are sound, but the cases themselves and commentary on them are at sea in an important way. They fail to articulate any criteria for fixing the boundaries of liability. Line drawing, we are told, must be arbitrary. This is an exaggeration. Principles are not precise enough to dictate the exact contours of lines, but good ones can guide the drawing of lines. The predicament of NIED liability is that it has a sound taxonomy, but no clear principle of recovery.

There is, however, principled guidance to be had, and it comes from the concept of harm itself. Harm involves the impairment of agency. To be harmed physically is to be subjected to a condition, which thwarts the normal use of one's body. Physical impairments—broken bones, crippled limbs, disfigured faces, serious illnesses-are an enduring and fundamental threat to our agency. Physical integrity is foundational to our agency. Psychological integrity plays a similar role in our lives and emotional distress is similarly capable of impairing our basic psychological capacities and profoundly diminishing our lives. The law of NIED should therefore take its cue from the idea of harm as impairment, and extend liability to those instances of emotional distress which either impair the capacities of those they afflict, or-by destroying a deep investment of agency—profoundly diminish their lives.

In distinguishing enduring emotional harm from transient emotional distress the law of negligence must be sensitive to the core and periphery of psychological harm. Core psychological harms impair basic capacities and enduringly so. Childhood sexual abuse leaves capacities for love and trust permanently damaged. Less central psychological harms inflict irreversible injury on fundamental life projects and force the construction of new lives. In bounding liability the law should seek to respect these gradations and to allocate its protections accordingly. This path opens the possibility of drawing distinctions more compelling than that between witnessing the death of one's child contemporaneously and learning of it over the phone. Perhaps more importantly, attending to the distinctive features of harm allows us to see that some recovery for NIED is both proper and important. Harm is the fundamental topic of tort and some emotional distress counts as profound harm. At present, American law perceives this truth through a glass darkly. We do not need to be born anew in order to discern more clearly when and why emotional distress is, or marks, the infliction of serious harm. 
